\title{
Prediction of Potato Tuber Damage by Root-Knot Nematodes using Quantitative DNA Assay of Soil
}

Frank S. Hay, School of Integrative Plant Science, Section of Plant Pathology and Plant-Microbe Biology, Cornell University, Geneva, NY 14456; Herdina and Kathy Ophel-Keller, South Australian Research Development Institute, Urrbrae, SA 5064, Australia; Diana M. Hartley, CSIRO National Research Collections Australia, Canberra, ACT 2601, Australia; and Sarah J. Pethybridge, School of Integrative Plant Science, Section of Plant Pathology and Plant-Microbe Biology, Cornell University, Geneva, NY 14456

\begin{abstract}
Hay, F. S., Herdina, Ophel-Keller, K., Hartley, D. M., and Pethybridge, S. J. 2016. Prediction of potato tuber damage by root-knot nematodes using quantitative DNA assay of soil. Plant Dis. 100:592-600.

Root-knot nematodes (Meloidogyne fallax and M. hapla) cause significant reductions in potato yield by reducing tuber quality. Concentrations of M. fallax and M. hapla DNA in soil were determined by quantitative polymerase chain reaction following sampling at planting and harvest within 78 fields across 3 years in Australia. Meloidogyne spp. were also detected using a tomato bioassay. M. fallax was more prevalent than $M$. hapla and DNA concentrations of $M$. fallax in soil were significantly higher in samples collected at harvest compared with those at planting. In contrast, $M$. hapla DNA in soil did not significantly change from planting to harvest. Using receiver operating characteristic curve analysis,

M. fallax DNA in soil at planting and harvest was a highly accurate predictor of tuber damage at harvest and galling on tomato. Prediction accuracy for tuber damage was highest for M. fallax DNA compared with M. hapla or M. fallax + M. hapla. Both Meloidogyne spp. were detected in the peel of asymptomatic certified seed. For M. fallax, the addition of seedborne inoculum did not improve tuber damage predictions. This suggested that soilborne $M$. fallax populations contributed most substantially to tuber damage. These findings highlight the utility of this approach for predicting risk of crop damage from nematodes. The use of this technique as a practical management tool is discussed.
\end{abstract}

The root-knot nematodes (Meloidogyne spp.) are important pathogens of potato (Solanum tuberosum L.) worldwide which may deleteriously affect productivity and profitability (Stevenson et al. 2001). Feeding by root-knot nematodes can cause reductions in the number of tubers and negatively affect quality due to blistering of the tuber surface, plus necrotic spots in the tuber flesh associated with egg masses under the epidermis (Vovlas et al. 2005). As potato is commonly affected by a spectrum of soilborne diseases, it is challenging to quantify losses associated solely with plant-parasitic nematodes. As a consequence, economic losses due to root-knot nematodes in Australian potato fields are not well documented. In Tasmania, Australia, Meloidogyne fallax and M. hapla are the predominant root-knot nematode species in vegetable cropping fields where processing potato is an integral crop within the rotation (Hay and Pethybridge 2005).

The tolerance limit for damage by root-knot nematodes in Australian seed potato is $2 \%$ of tubers (Anonymous 2007). In some years, symptoms caused by root-knot nematodes have been the most common cause of rejection of seed potato crops. For example, in 2007, 39\% of seed potato was rejected from the Australian certification scheme due to damage from root-knot nematodes, equating to a loss of AUD\$420,000. Individual losses to growers can be substantial because detection can lead to entire crops being rejected at harvest. Similarly, in Idaho, fresh-market potato fields may be rejected if at least $5 \%$ of tubers have visual defects from M. chitwoodi, and processed potato fields may be rejected or devalued if 5 to $15 \%$ of tubers exhibit symptoms (King and Taberna 2013).

Decisions regarding the management of root-knot and other plantparasitic nematodes are often required before planting with concomitant prophylactic applications of costly fumigants or nematicides.

Corresponding author: F. S. Hay; E-mail: fsh32@cornell.edu

Accepted for publication 30 July 2015.

http://dx.doi.org/10.1094/PDIS-05-15-0537-RE

(C) 2016 The American Phytopathological Society
This risk-averse management practice has resulted in low crop losses incurred from nematode infections and disease. However, in some cases, growers may apply fumigants and nematicides unnecessarily and make false-positive decisions with adverse effects on crop returns, beneficial soil microorganism populations, and potential for off-site, deleterious effects on environments. This is because population levels may be insufficient to cause economic damage, or spatial aggregation of nematode populations may imply that fields with low population densities are being treated unnecessarily. For example, King and Taberna (2013) used site-specific fumigation for control of M. chitwoodi in 640 ha of potato in eastern Idaho based on intensive grid-based sampling, and achieved an average $30 \%$ reduction in fumigant usage without compromising yield, translating to an average saving of $\$ 209 /$ ha in chemical costs. However, at present, intensive soil sampling is costly and dependent upon labor intensive techniques.

Traditional methods of detection and quantification of nematodes in soil involve extraction of nematodes or eggs from a known weight or volume of soil (Shurtleff and Averre 2000; Viglierchio and Schmitt 1983; Whitehead and Hemming 1965). However, these techniques only extract a proportion of vermiform nematodes and those hatching from eggs during extraction. Nematodes or eggs are then enumerated, at which time vermiform nematodes can often only be identified to genus and the identity of eggs cannot be determined. Identification to species often requires heat killing, fixing, and mounting individual nematodes on slides for detailed morphological observations at high magnification. This process requires a highly skilled nematologist and is laborious and technically difficult; therefore, only a small subsample can be practically identified to species. Poor efficiency of extraction methods can further reduce the predictive utility of population density estimates using these techniques and associated crop damage.

As an alternative, bioassays for root-knot nematodes are generally more sensitive than manual extraction (Bélair 1998) and have been used to inform management decisions (Gugino et al. 2008). However, bioassays are labor intensive and time consuming. Other methods of quantifying risk before planting from root-knot nematodes have involved determining the relationship between damage 
in the previous (if susceptible) crop and future crops. For example, Bélair and Boivin (1988) determined that an average gall rating of 1.6 in carrot equated to yield loss equivalent to the cost of nematicides. Moreover, an average gall rating of 0.7 for the carrot crop of the previous season equated to an average gall rating of 1.6 in the crop of interest. This information was used to devise a sequential sampling plan at harvest in the previous crop to inform risk before planting (Bélair and Boivin 1988). However, this technique has limited utility in a diverse rotation where the crop planted in the field subsequently may not be a host or may be less susceptible to rootknot nematodes.

Quantitative real-time polymerase chain reaction (qPCR) has provided substantial advances in enhancing our understanding of inoculum densities in the development of monocyclic soilborne diseases, including those caused by nematodes (Berry et al. 2008; Bilodeau 2011; Bilodeau et al. 2012; Cullen et al. 2005; Deora et al. 2015; Madani et al. 2005; Yan et al. 2012, 2013). In Australia, a commercial soil testing service called PreDicta B which quantifies the DNA of several fungal and nematode pathogens has been available to the cereal industry since 1997 (Ophel Keller et al. 2008). A service (PreDicta Pt) was established for Australian potato growers in 2014 (Ophel-Keller et al. 2009). The objectives of this study were to: (i) describe the prevalence and population densities of root-knot nematodes in potato fields in northern Tasmania, Australia; (ii) quantify the utility of the PreDicta Pt test for predicting damage caused by root-knot nematodes to potato in comparison with a tomato galling bioassay; and (iii) model the contribution of seed tuber-borne and soilborne inoculum to potato tuber damage incurred by root-knot nematodes. This information is critical for a holistic assessment of the cost savings that may be realized from using risk assessments based on qPCR for the control of root-knot nematodes.

\section{Materials and Methods}

Prevalence and population densities of root-knot nematodes. The prevalence and population densities of root-knot nematodes in commercial processing potato fields were quantified in $2010(n=$ $22)$ and $2011(n=31)$. Fields were located within $70 \mathrm{~km}$ of the northern coastline of Tasmania, Australia and extended from Natone $\left(41^{\circ} 16^{\prime} \mathrm{S}, 145^{\circ} 92^{\prime} \mathrm{E}\right)$ to Winnaleah $\left(41^{\circ} 10^{\prime} \mathrm{S}, 147^{\circ} 83^{\prime} \mathrm{E}\right)$. Approximately $1.8 \mathrm{~kg}$ of soil was collected across a grid from 36 equidistant sample points within a 1-ha area of the field up to 3 weeks before planting in October and November of each year. At each point, three core samples (15 cm deep by $1 \mathrm{~cm}$ in diameter) were collected with an Accucore sampler (Spurr Soil Probes, Adelaide, Australia) and bulked across the 36 sampling locations. Each point was geospatially referenced (Garmin eTrex; Garmin Australasia Pty. Ltd., Sydney, Australia) to allow resampling of sample points at commercial harvest (March to May). Soil from each point was thoroughly mixed, a subsample of soil was dried $\left(40^{\circ} \mathrm{C}\right.$ for $\left.48 \mathrm{~h}\right)$, and $500 \mathrm{~g}$ was processed for DNA extraction (Haling et al. 2011; Ophel Keller et al. 2008, 2009).

The remainder of the soil collected from each point was placed in 20-cm-diameter pots and used for a greenhouse bioassay. Threeweek-old tomato seedlings ('Tiny Tim') were planted as bioassay bait plants into the pots and maintained in a greenhouse at 20 to $25^{\circ} \mathrm{C}$ for a sufficient amount of time for one generation of $M$. hapla to occur (42 days) (Insera et al. 1982; Melakeberhan et al. 2007). Plants were destructively harvested and roots washed and examined for the presence of galling.

At harvest, one tuber was collected from each geospatially referenced sampling point within each field. Tubers were washed free of soil and the presence of damage caused by root-knot nematodes assessed visually. Damage from root-knot nematodes was defined as characteristic abnormalities or blistering of the tuber surface (Anonymous 2007).

In 2012, soil samples were collected from 25 potato fields across northern Tasmania in the same area as in previous years. Each circular (pivot-irrigated) field was bisected into four quadrants, and a geospatially referenced plot $\left(80 \mathrm{~m}^{2}\right)$ was established in each quadrant. Soil was collected at 40 sampling points along a W-shaped transect within each plot, with 10 sample points on each transect arm at planting in October and November. Two soil cores were collected in the same manner as in previous seasons at each of the sample points for a total of approximately $1.2 \mathrm{~kg}$ of soil collected per plot. Plots were sampled before harvest between March and April of the subsequent year. A 600-g subsample of soil from each quadrant was dried at $40^{\circ} \mathrm{C}$ for $48 \mathrm{~h}$ in shallow trays within $48 \mathrm{~h}$ of collection for DNA extraction (Haling et al. 2011; Ophel-Keller et al. 2008).

To quantify the incidence of tuber seed infested with root-knot nematodes, 50 individual seed pieces were collected at the ends of rows from each quadrant at planting. Peel samples (approximately 5-mm peel depth) were dried at $40^{\circ} \mathrm{C}$ for $48 \mathrm{~h}$ prior to DNA extraction (Tegg et al. 2015). Remaining soil from 17 of the 25 fields was placed in pots for a greenhouse bioassay (as described). At harvest, a tuber was collected from each of the 40 sampling points within a plot and assessed visually for damage caused by root-knot nematodes. The incidence of tubers with damage per quadrant was calculated.

qPCR for root-knot nematodes. qPCR assays for M. fallax and $M$. hapla were used in this study. For each species, specific primers and TaqMan Minor Groove Binder probes were designed within the internal transcribed spacer (ITS) ribosomal RNA region using Primer Express v2.0.0 (Applied Biosystems, Foster City, CA). ITS sequences of the target and closely related species were downloaded from GenBank (National Center for Biotechnology Information) (Benson et al. 2013) and aligned in Bioedit v7.2.1 (Hall 1999). A number of primers and probe sets were identified and these were evaluated for specificity and sensitivity against a range of target and nontarget nematodes. The nontarget nematodes included Ditylenchus dipsaci, Globodera pallida, G. rostochiensis, Heterodera avenae, $H$. schachtii, $H$. trifolii, M. arenaria, M. incognita, M. javanica, M. trifoliophila, Pratylenchus neglectus, P. penetrans, P. quasitereoides, $P$. thornei, $P$. zeae, and Radopholus similis. The specificity of the two assays was also assessed against a range of free-living nematodes, including bacterivores, fungivores, omnivores, and predators. For the M. fallax test, forward $5^{\prime}$-ACATGT TAGGATTCTTTTTATAAGAATCG-3' and reverse 5'-CGAGT $^{\prime}$ GATCCACCGGTAAGG-3' primers and TaqMan probe 6FAM 5'-ACGCCAGCACCCAT-3' were selected. For the $M$. hapla test, forward primer $5^{\prime}$-TTCGAATAGTCTCAACGTTTATCGTT-3', reverse primer $5^{\prime}$-GGCTCATTAAGTCTTAAACCCGATTA- ${ }^{\prime}$ and TaqMan probe 6FAM 5'-ACACCTAGACACCAGCGA-3' were used. The qPCR was performed using the ViiA7 real-time PCR system (Applied Biosystems) in a 10- $\mu$ l volume reaction containing Qiagen QuantiTect Probe Master Mix (1×), forward and reverse primers (400 $\mathrm{mM}$ each), and probe (200 mM). Nematode DNA concentration was estimated and $40 \mathrm{pg}$ of DNA was used for the specificity test. Thermal cycling conditions consisted of an initial denaturation at $95^{\circ} \mathrm{C}$ for $15 \mathrm{~min}$, followed by 40 cycles of $95^{\circ} \mathrm{C}$ for $15 \mathrm{~s}$ (denaturation) and $1 \mathrm{~min}$ at $60^{\circ} \mathrm{C}$ (combined annealing and extension).

DNA extracted from nematode eggs collected from tomato plants artificially inoculated with either M. fallax or M. hapla was used to calibrate each assay. These two nematodes were identified by their perineal patterns and host ranges, as described by Taylor and Sasser (1978). The eggs were collected using the method described by Walker (2000). Nematode DNA concentration was determined using the QuantiFluor dsDNA system (Promega Corp., Madison, WI), and a serial dilution of Promega $\lambda$ DNA/HindIII marker was used as standard. A 10-fold dilution series of M. fallax and M. hapla DNA from $200 \mathrm{pg} / \mu \mathrm{l}$ to $2 \mathrm{fg} / \mu \mathrm{l}$, respectively, was prepared to generate a standard curve for each assay. These were used to convert cycle threshold $\left(\mathrm{C}_{\mathrm{t}}\right)$ values (the number of cycles taken to reach the PCR threshold) to DNA concentration.

Soil DNA samples and nematodes were extracted by the commercial testing service provided by the Root Disease Testing Service of the South Australian Research Development Institute, Adelaide, South Australia, Australia (Haling et al. 2011; Ophel Keller et al. 2009; Tegg et al. 2015). For each soil and tuber sample, one qPCR was conducted. An internal control DNA was added to each sample prior to extraction and used to monitor DNA extraction efficiency and detect the presence of potential PCR inhibitors. 
Data analysis. Paired, two-sample, and one-tailed $t$-tests were used to test whether the distribution of M. fallax and M. hapla DNA in soil and tubers collected at planting and harvest were significantly different (Genstat, version 17; Hemel Hempstead, United Kingdom). Relationships were explored between soil DNA (picograms per gram of dried soil) and predicted variables: (i) the proportion of fields in which tuber damage due to root-knot nematodes was detected on tubers at harvest and (ii) the proportion of fields in which galling was observed in bioassay plants.

Receiver operating characteristic (ROC) curve analysis was used to select appropriate cut points for the operational use of soil DNA (picograms per gram of dried soil) as a predictor of crop damage and galling, and the role of seedborne inoculum in crop damage (Bewick et al. 2004; Lloyd 2000; Pethybridge et al. 2009; Turechek and Wilcox 2005; Turechek et al. 2008). ROC curves were generated by plotting sensitivity (true positive proportion) on the vertical axis with 1-specificity (false positive proportion) on the horizontal axis. If the predictor is of high accuracy, the curve will rise rapidly to the top left-hand corner of the graph and flatten. Conversely, if the curve follows a diagonal line from bottom left to top right, this indicates that the test has a predictive accuracy no better than random chance and there is an equal chance of predicting a true positive or a false positive. The area under the ROC curve (AUROC) was calculated for each curve (Hanley and McNeil 1982). AUROC is an overall measure of predictive ability and has values between 0.5 and 1 . As the AUROC moves closer to 1, this indicates that the predictor is of high discriminatory power. If the AUROC is less than 0.5 , the test has predictive value no better than random chance (Bewick et al. 2004; Fischer et al. 2003).

Sensitivity and specificity were calculated for various cut point values for soil DNA. Sensitivity was defined as the proportion of fields above each cut point correctly identified as having tuber damage due to root-knot nematodes. Specificity was defined as the proportion of fields below the cut point correctly identified as not having tuber damage from root-knot nematodes. For the calculation of Youden's index, $J=$ sensitivity + specificity -1 ; sensitivity and specificity were regarded as of equal importance (Madden et al. 2007; Youden 1950). Youden's index has a maximum of $J=1$ when the test is a perfect predictor, and $J=0$ when the test has no diagnostic value (Youden, 1950 ). The cut point associated with the highest level of $J$ was considered optimal (Bewick et al. 2004).

\section{Results}

Prevalence and population densities of root-knot nematodes determined by qPCR. The qPCR assays for M. fallax and M. hapla developed in this study specifically detected their respective targets with high sensitivity. Each assay detected only the target DNA, with $\mathrm{C}_{\mathrm{t}}$ values of 21.3 for $40 \mathrm{pg}$ of either M. fallax or M. hapla DNA. The efficiency of the M. fallax and M. hapla assays was 97 and $94 \%$, respectively.

In the 2010 and 2011 surveys conducted at planting, M. fallax and M. hapla were detected in 62 and $25 \%$ of fields, respectively

Table 1. Prevalence of Meloidogyne fallax and M. hapla detected by quantitative polymerase chain reaction in soil in potato fields at planting and harvest in Tasmania, Australia in 2010 and 2011

\begin{tabular}{lcccc}
\hline \multirow{2}{*}{$\begin{array}{l}\text { Sample time, } \\
\text { nematode }\end{array}$} & $\begin{array}{c}\text { Prevalence } \\
(\boldsymbol{\%})\end{array}$ & \multicolumn{3}{c}{ DNA (pg/g of dried soil) } \\
\cline { 4 - 5 } & & Mean & Standard deviation & Range \\
\hline $\begin{array}{l}\text { Planting } \\
\text { M. fallax }\end{array}$ & 62.2 & 32.9 & 68.2 & $0.09-353.7$ \\
$\quad$ M. hapla & 24.5 & 32.2 & 79.5 & $0.32-281.0$ \\
Harvest & & & & \\
M. fallax & 71.7 & 231.4 & 421.3 & $0.34-1,888.0$ \\
M. hapla & 47.2 & 84.9 & 273.9 & $0.06-1,374.4$ \\
\hline
\end{tabular}

a Mean, standard deviation, and range were calculated using data only from fields in which $M$. fallax and $M$. hapla were detected.

b $M$. fallax and $M$. hapla were detected in mixed populations in 23 and $42 \%$ of fields at planting and harvest, respectively. Total number of fields $=53$.
(Table 1). Upon resampling before harvest, M. fallax and M. hapla were detected in an additional 9 and $22 \%$ of fields, respectively. M. fallax and M. hapla were found together in the same field in $23 \%$ of fields at planting and $42 \%$ of fields at harvest. The mean DNA concentration of $M$. fallax in soil before planting was $32.9 \mathrm{pg} / \mathrm{g}$ of dried soil and, by harvest, had increased sevenfold $(t=-3.19, P=0.001$; Table 1). The mean DNA concentration of $M$. hapla in soil collected at planting was $32.2 \mathrm{pg} / \mathrm{g}$ of dried soil, which increased 2.6 times by harvest but was not significantly different from concentrations in soil at planting $(t=-1.3, P=0.099)$. The mean DNA concentration of $M$. hapla in soil at harvest was significantly less than that of $M$. fallax $(t=2.58, P=0.006$; Table 1$)$.

In 2012, M. fallax and M. hapla were detected in 76 and $56 \%$ of potato fields $(n=25)$, respectively, and the two species were detected together in $52 \%$ of fields at planting. The mean concentration of M. fallax DNA sampled at planting was $29.8 \mathrm{pg} / \mathrm{g}$ of dried soil, which significantly increased threefold by harvest $(t=-4.07, P<0.0001)$. The mean concentration of $M$. hapla DNA at planting was $34 \mathrm{pg} / \mathrm{g}$ of dried soil, which was not significantly different from that at harvest $(t=-0.37, P=0.646$; Table 2).

M. fallax and M. hapla were detected in the peel of seed tubers from 62 and $40 \%$ of plots, respectively. The mean concentrations of $M$. fallax and $M$. hapla DNA in the peel of seed tubers were 189.8 and $85.0 \mathrm{pg} / \mathrm{g}$, respectively (Table 2). All seed tubers were asymptomatic. At harvest, M. fallax was detected in the peel of $60 \%$ of tubers but at concentrations not significantly different than those detected in seed tubers $(t=-0.99, P=0.162)$. No significant differences were detected in $M$. hapla DNA concentration in the peel of seed and harvested tubers $(t=1.49$, $P=0.069$; Table 2).

Prediction of tuber damage as a function of root-knot nematode DNA. ROC curves for soilborne DNA at planting for M. fallax and combined $M$. fallax $+M$. hapla as a predictor of tuber damage at harvest were highly significant, with similar AUROC (Figs. 1 and 2; Table 3). M. hapla DNA in soil at planting as a predictor of nematode damage to tubers at harvest was not significantly different $(P=0.128$; Table 3). The optimal cut point for M. fallax was $2.90 \mathrm{pg} / \mathrm{g}$ of dried soil, which correctly predicted the presence and absence of tuber damage in 75 and $82 \%$ of fields, respectively (Fig. 1; Table 3). The optimal cut point for the sum of M. fallax + M. hapla DNA at planting was $0.90 \mathrm{pg} / \mathrm{g}$ of dried soil, which correctly predicted the presence or absence of tuber damage in 85 and $73 \%$ of fields, respectively (Fig. 2; Table 3).

Table 2. Prevalence of Meloidogyne fallax and M. hapla detected by quantitative polymerase chain reaction at planting and harvest from soil and peel of tubers in potato plots in Tasmania, Australia in 2012

\begin{tabular}{|c|c|c|c|c|}
\hline \multirow{2}{*}{$\begin{array}{l}\text { Sample time, } \\
\text { nematode }\end{array}$} & \multirow[b]{2}{*}{ Prevalence $(\%)^{\mathbf{b}}$} & \multicolumn{3}{|c|}{ DNA $(\mathbf{p g} / \mathbf{g})^{\mathbf{a}}$} \\
\hline & & Mean & SD & Range \\
\hline \multicolumn{5}{|l|}{ Planting (soil) } \\
\hline M. fallax & 53 & 29.8 & 61.3 & $0.08-371$ \\
\hline M. hapla & 35 & 34.0 & 88.1 & $0.16-479$ \\
\hline \multicolumn{5}{|l|}{ Harvest (soil) } \\
\hline M. fallax & 61 & 92.2 & 126.1 & $0.07-570$ \\
\hline M. hapla & 33 & 44.3 & 77.8 & $0.29-313$ \\
\hline \multicolumn{5}{|c|}{ Peel in tuber seed } \\
\hline M. fallax & 62 & 189.8 & 429.3 & $1.30-3,006$ \\
\hline M. hapla & 40 & 85.0 & 261.9 & $1.0-1,526$ \\
\hline \multicolumn{5}{|c|}{ Peel in tubers at harvest } \\
\hline M. fallax & 60 & 292.4 & 712.9 & $1.22-5,123$ \\
\hline M. hapla & 19 & 33.0 & 60.3 & $1.52-242$ \\
\hline
\end{tabular}

${ }^{a}$ Mean, standard deviation (SD), and range were calculated using data only from plots in which the M. fallax and M. hapla were detected. For peel samples, total number of plots $=92$.

b M. fallax and M. hapla were detected together in 29 and $25 \%$ of 100 plots at planting and harvest, respectively. M. fallax and M. hapla were detected in the same peel samples in 20/92 and 16/92 of samples at planting and harvest, respectively. 
ROC curves for M. fallax, M. fallax $+M$. hapla, and M. hapla in soil at harvest were also highly significant predictors of damage from root-knot nematodes to tubers $(P<0.0004$; Figs. 1 to 3; Table 3). AUROC was higher for the relationship between $M$. fallax and tuber damage than for either M. hapla or M. fallax + M. hapla. The optimal cut point for M. fallax DNA at harvest was $57.94 \mathrm{pg} / \mathrm{g}$ of dried soil, which correctly predicted the presence or absence of tuber damage in
80 and $97 \%$ of fields, respectively. The optimal cut point for M. fallax + M. hapla DNA at harvest was higher than for M. fallax alone, and sensitivity and specificity were reduced (Table 3 ).

DNA for M. fallax, M. hapla, and M. fallax + M. hapla at planting and harvest were highly significant $(P \leq 0.011)$ predictors of galling on tomato in soil collected at harvest (Figs. 1 to 3; Table 4). For soil collected at planting, the optimal cut point for M. fallax DNA was
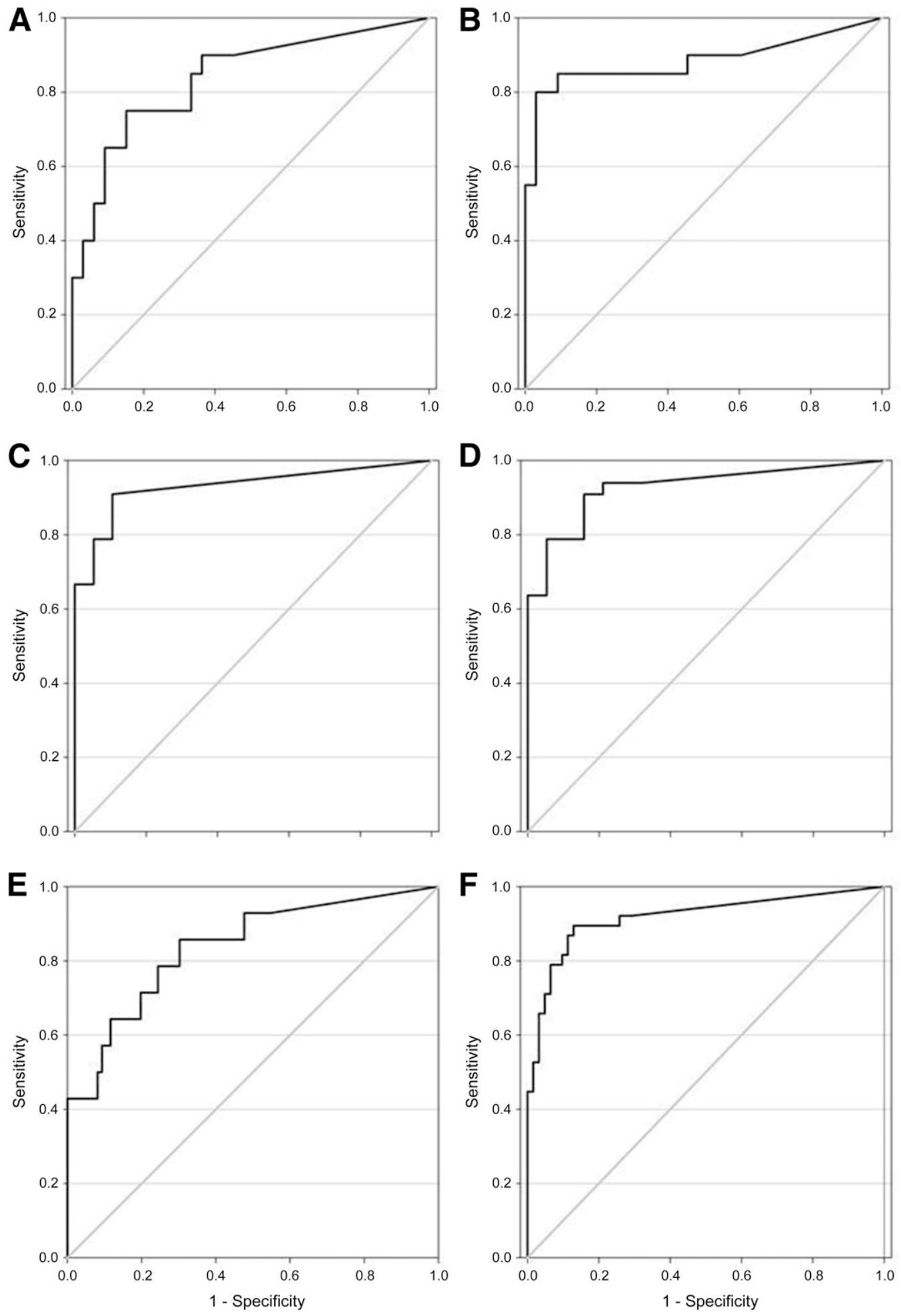

Fig. 1. Receiver operating characteristic curves for models classifying potato tuber damage and galling on tomato 'Tiny Tim' as a function of Meloidogyne fallax DNA detected in soil (picograms per gram) by quantitative polymerase chain reaction in Tasmania, Australia. The 1:1 gray line represents a noninformative predictor with predictions no better than random chance. A and B, Tuber damage and DNA in soil collected at planting and harvest, respectively, in 2010 and 2011. C and D, Relationship between galling in tomato and DNA in soil collected at planting and harvest, respectively, in 2010 and 2011. E, Tuber damage at harvest as predicted by DNA in peel of tubers at harvest. F, Frequency of tubers collected at harvest with DNA at greater than $24 \mathrm{pg} / \mathrm{g}$ in the dried peel at harvest (as a potential indicator of tuber damage) and DNA in the soil collected at planting 
$0.04 \mathrm{pg} / \mathrm{g}$ of dried soil, correctly predicting the presence or absence of galling on tomato in 91 and $89 \%$ of fields, respectively. For M. fallax + M. hapla, the optimal cut point was also $0.04 \mathrm{pg} / \mathrm{g}$ of dried soil at planting. However, for $M$. hapla alone, the optimal cut point was fourfold higher with low sensitivity (Table 4).

Significant relationships were also observed between root-knot nematode DNA and galling on tomato grown in soil collected at harvest for each species alone or combined, with AUROC values ranging between 0.83 and 0.97 . The cut point for DNA of $M$. fallax and M. fallax + M. hapla both occurred at $1.81 \mathrm{pg} / \mathrm{g}$ of dried soil. For M. hapla, the optimal cut point was $0.04 \mathrm{pg} / \mathrm{g}$ of dried soil (Table 4).

Role of seedborne inoculum in predicting tuber damage. The concentration of $M$. fallax DNA (picograms per gram) in soil at planting, in soil and peel at harvest as individual factors, and in soil + peel at planting were all highly significant $(P \leq 0.012)$ predictors of damage from root-knot nematodes on tubers at harvest (Fig. 1; Table 5). In contrast, $M$. fallax DNA in peel at planting was not a significant $(P=0.704)$ predictor of tuber damage. Moreover, the sum of $M$. fallax DNA in soil + peel at planting had less predictive strength than M. fallax DNA in soil only at planting. For soil collected at planting, the optimal cut point of M. fallax DNA was $1.2 \mathrm{pg} / \mathrm{g}$ of dried soil, with sensitivity and specificity at least 0.71 (Table 5).

The concentration of M. hapla DNA in soil or peel alone, regardless of collection time, was not a significant $(P>0.05)$ predictor of damage on tubers (Table 5). However, the sum of M. fallax + M. hapla DNA in soil sampled at planting provided significant $(P=0.006)$
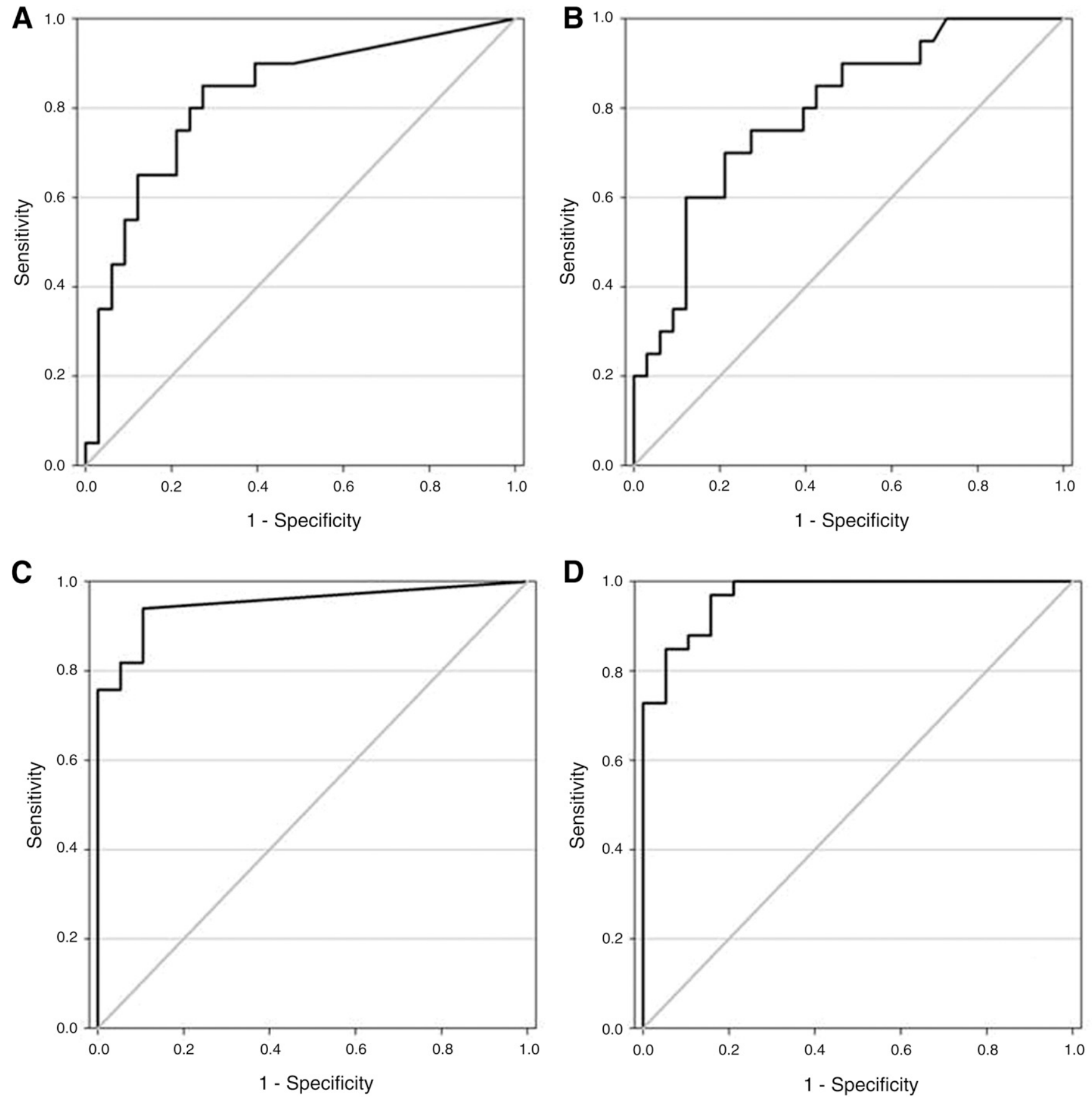

Fig. 2. Receiver operating characteristic curves for models classifying $\mathbf{A}$ and $\mathbf{B}$, potato tuber damage and $\mathbf{C}$ and $\mathbf{D}$, galling on tomato 'Tiny Tim' as a function of Meloidogyne spp. (Meloidogyne fallax and M. hapla) DNA detected in soil (picograms per gram) by quantitative polymerase chain reaction in Tasmania, Australia. A and C, Potato tuber damage and galling on tomato, respectively, and Meloidogyne spp. DNA in soil collected at planting. B and D, Potato tuber damage and galling on tomato, respectively, and Meloidogyne spp. DNA in soil collected at harvest. The 1:1 gray line represents a noninformative predictor with predictions no better than random chance. 
prediction of damage on tubers, with an optimal cut point of 5.21 $\mathrm{pg} / \mathrm{g}$ of dried soil, and similar AUROC, significance, sensitivity, and specificity to the concentration of $M$. fallax in soil (Table 5).

Using M. fallax DNA in harvested tuber peel as a predictor of tuber damage, an optimal cut point of $24.3 \mathrm{pg} / \mathrm{g}$ of dried peel was identified, with a sensitivity of $86 \%$ and specificity of $70 \%$ (Table 5). The relationship between $M$. fallax DNA in soil at planting as a predictor of M. fallax DNA greater than $24.3 \mathrm{pg} / \mathrm{g}$ in peel at harvest was also highly significant (AUROC $=0.917, P<0.0001$ ), with an optimal cut point of $0.59 \mathrm{pg} / \mathrm{g}$ of soil at planting, and sensitivity and specificity of 90 and $87 \%$, respectively (Fig. 1E and F).

\section{Discussion}

M. fallax was more prevalent than M. hapla in Tasmanian potato fields despite the former not being recognized in Tasmania until recently (Hay and Pethybridge 2005). The widespread nature of M. fallax is likely to be due, at least in part, to dissemination by infested tuber seed. The host range of M. fallax and M. hapla includes crops which are grown in rotation with potato (e.g., carrot); however,
M. fallax can also reproduce on monocotyledons such as wheat and barley (den Nijs et al. 2004).

M. fallax is closely related to M. chitwoodi (van der Beek and Karssen 1997), which is more prevalent than M. hapla in the Pacific Northwest. The dominance of M. chitwoodi over M. hapla in this region has been attributed to the ability of the former to invade potato at lower temperatures and develop more rapidly over a wider temperature range (Insera et al. 1982; O'Bannon and Santo 1984; Santo and O'Bannon 1981a), and the ability of $M$. chitwoodi to reproduce on grains often grown in rotation with potato (Santo and O'Bannon 1981b).

In this study, $M$. fallax DNA in soil collected at planting was a highly significant predictor of the presence of tuber damage, with AUROC values of 0.838 and 0.771 in 2010 to 2011 and 2012, respectively. The magnitude of these values suggested that DNA of $M$. fallax was a moderately accurate predictor of tuber damage (Fischer et al. 2003). Results between years were consistent with optimal cut points, of M. fallax DNA at 2.9 and $1.2 \mathrm{pg} / \mathrm{g}$ of dried soil collected at planting in 2010 to 2011 and 2012, respectively.

Table 3. Prediction statistics for relationships between the DNA of Meloidogyne fallax, M. hapla, and M. fallax + M. hapla in soil at planting or harvest with potato tuber damage at harvest across 2010 and 2011

\begin{tabular}{|c|c|c|c|c|c|c|c|}
\hline Nematode, sample time & $\operatorname{AUROC}( \pm \mathrm{SE})^{\mathbf{a}}$ & $95 \% \mathrm{CI}^{\mathrm{b}}$ & $P^{\mathrm{c}}$ & $J^{\mathrm{d}}$ & Cut point ${ }^{\mathrm{e}}$ & Sens $^{\mathrm{f}}$ & Spec $^{g}$ \\
\hline \multicolumn{8}{|l|}{ M. fallax } \\
\hline Planting & $0.838(0.059)$ & $0.721-0.954$ & $<0.0001$ & 0.57 & 2.90 & 0.75 & 0.82 \\
\hline Harvest & $0.885(0.058)$ & $0.770-0.999$ & $<0.0001$ & 0.77 & 57.94 & 0.80 & 0.97 \\
\hline \multicolumn{8}{|l|}{ M. hapla } \\
\hline Planting & $0.626(0.082)$ & $0.464-0.787$ & $0.128(\mathrm{~ns})$ & 0.28 & 0.76 & 0.35 & 0.91 \\
\hline Harvest & $0.743(0.072)$ & $0.602-0.885$ & 0.0032 & 0.48 & 0.06 & 0.75 & 0.73 \\
\hline \multicolumn{8}{|l|}{ M. fallax + M. hapla } \\
\hline Planting & $0.823(0.062)$ & $0.702-0.943$ & $<0.0001$ & 0.58 & 0.90 & 0.85 & 0.73 \\
\hline Harvest & $0.792(0.063)$ & $0.668-0.915$ & 0.0004 & 0.49 & 102.10 & 0.70 & 0.79 \\
\hline
\end{tabular}

${ }^{\text {a }}$ Area under the receiver operating characteristic curve ( \pm standard error [SE]; Hanley and McNeil 1982).

b Confidence interval (CI) for AUROC.

c Abbreviation: $\mathrm{ns}=$ not significant.

d Youden's Index.

e Cut point defined as the point on the ROC curve furthest to the diagonal line representing a noninformative predictor used to dichotomize predictions of fields

${ }^{\mathrm{f}}$ Sensitivity = percentage of fields classified correctly as being over the cut-point threshold.

g Specificity = percentage of fields classified correctly as below the cut-point threshold.
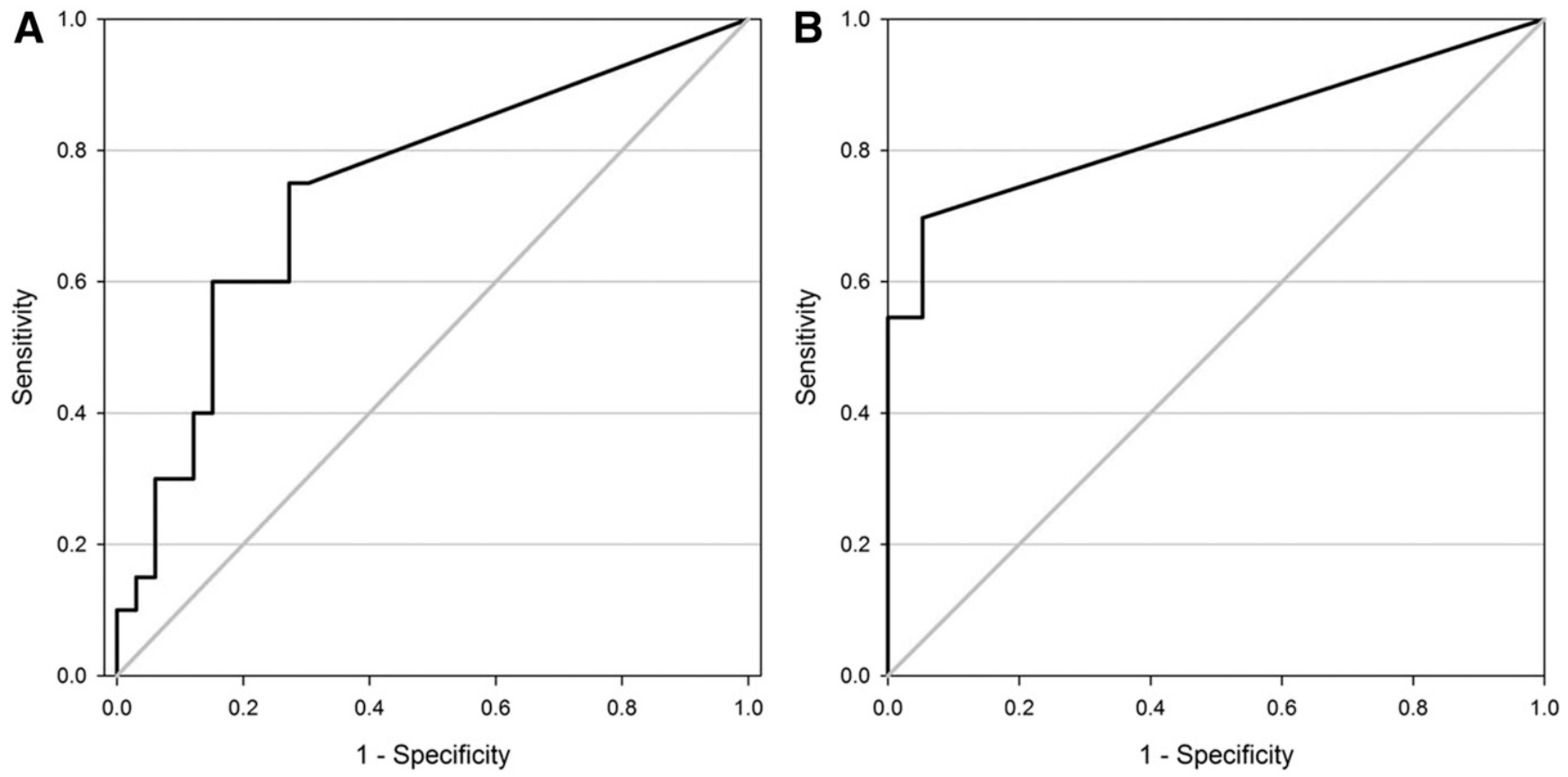

Fig. 3. Receiver operating characteristic curves for models classifying A, potato tuber damage and B, galling on 'Tiny Tim' tomato grown in soil collected at harvest as a function of Meloidogyne hapla DNA detected in soil (picograms per gram) collected at harvest by quantitative polymerase chain reaction in Tasmania, Australia. The 1:1 gray line represents a noninformative predictor with predictions no better than random chance. 
Results from qPCR were highly correlated with the frequency of detection of Meloidogyne spp. using the tomato bioassay, which is considered a highly sensitive technique to determine the presence of root-knot nematodes (Bélair 1998). This corroborates findings of previous research, which demonstrated significant relationships with high precision between qPCR, gall ratings on tomato, and the number of $M$. incognita second-stage juveniles by manual extractions (Stirling et al. 2004).

In our study, $M$. fallax DNA in soil generally provided improved predictions of tuber damage compared with M. hapla or M. fallax + M. hapla DNA. M. fallax is generally considered to be associated with a higher severity of tuber symptoms than M. hapla (Tegg et al. 2014). For Meloidogyne spp. that penetrate deeper within the tuber flesh, such as M. fallax and M. chitwoodi, major crop loss is incurred from deleterious effects on tuber quality (Griffin 1985; Pinkerton and Santo 1986). For these and other species of Meloidogyne, crop loss may also be associated with reductions in tuber yield. For example, nematicide application within a field with a high density of M. hapla led to a $90 \%$ increase in the yield of 'Pontiac' potato in the absence of any visual tuber damage (Stirling and Wachtel 1985). Therefore, further improvements in the predictive ability of nematode DNA may be made for these species by incorporating further quantification of crop loss such as reductions in tuber number and size.
In 2012, M. fallax DNA in soil at planting was a moderately accurate predictor of tuber damage from root-knot nematodes at harvest. Conversely, the concentration of M. fallax DNA in peel of tuber seed was not significant, and the sum of DNA in soil + peel at planting had a lower AUROC than M. fallax DNA in soil at planting alone. All fields were established with certified seed potato showing no visual damage from Meloidogyne spp. ( $\leq 2 \%$ incidence). Therefore, the detection of Meloidogyne spp. in seed at planting highlighted that visual inspection for damage was not sufficient to detect root-knot nematodes. Despite the potential for root-knot nematodes to be introduced into fields with certified seed, the contribution to daughter tuber damage was negligible in this study. Therefore, where visually certified seed potato was used, the relationship between DNA in soil at planting and tuber damage remained robust. However, in situations where visually damaged seed is used, seed may play a greater role as a determinant of damage in harvested tubers. In our study, a DNA concentration greater than $24 \mathrm{pg} / \mathrm{g}$ of peel on potato tubers at harvest was associated with the presence of visual symptoms on tubers. Moreover, soil DNA at planting provided a highly accurate prediction of M. fallax DNA above or below the $24 \mathrm{pg} / \mathrm{g}$ of dried peel threshold in 90 and $87 \%$ of plots, respectively (AUROC $=0.917$ ). This finding suggested that DNA of $M$. fallax in soil at planting could be used to accurately predict DNA levels in tuber peel at harvest, which may have utility for the production of certified seed.

Table 4. Prediction statistics for relationships between DNA of Meloidogyne fallax, M. hapla, and M. fallax + M. hapla in soil and incidence of tomato root galling in a greenhouse bioassay from samples collected from potato fields in 2010 and 2011

\begin{tabular}{|c|c|c|c|c|c|c|c|}
\hline Nematode, sample time & $\operatorname{AUROC}( \pm \mathrm{SE})^{\mathrm{a}}$ & $95 \% \mathrm{CI}^{\mathrm{b}}$ & $P$ & $J^{\mathbf{c}}$ & Cut point ${ }^{d}$ & Sens $^{e}$ & Spec $^{f}$ \\
\hline \multicolumn{8}{|l|}{ M. fallax } \\
\hline Planting & $0.931(0.036)$ & $0.860-1.001$ & $<0.0001$ & 0.80 & 0.04 & 0.91 & 0.89 \\
\hline Harvest & $0.927(0.036)$ & $0.855-0.998$ & $<0.0001$ & 0.75 & 1.81 & 0.91 & 0.84 \\
\hline \multicolumn{8}{|l|}{ M. hapla } \\
\hline Planting & $0.712(0.070)$ & $0.575-0.849$ & 0.011 & 0.42 & 0.16 & 0.42 & 1.00 \\
\hline Harvest & $0.833(0.056)$ & $0.724-0.942$ & $<0.0001$ & 0.64 & 0.04 & 0.70 & 0.95 \\
\hline \multicolumn{8}{|l|}{ M. fallax $+M$. hapla } \\
\hline Planting & $0.951(0.030)$ & $0.893-1.008$ & $<0.0001$ & 0.83 & 0.04 & 0.94 & 0.89 \\
\hline Harvest & $0.970(0.020)$ & $0.931-1.009$ & $<0.0001$ & 0.81 & 1.81 & 0.97 & 0.84 \\
\hline
\end{tabular}

a Area under the receiver operating characteristic curve ( \pm standard error $[\mathrm{SE}])$.

b Confidence interval (CI) for AUROC.

c Youden's Index.

${ }^{d}$ Cut point defined as the point on the ROC curve furthest to the diagonal line representing a noninformative predictor used to dichotomize predictions of fields.

e Sensitivity = percentage of fields classified correctly as being over the cut point threshold.

${ }^{\mathrm{f}}$ Specificity $=$ percentage of fields classified correctly as below the cut point threshold.

Table 5. Prediction statistics for relationships between DNA of Meloidogyne fallax, M. hapla, and M. fallax + M. hapla in soil or peel at planting or harvest and the presence of damage on potato tubers from samples collected in 2012

\begin{tabular}{|c|c|c|c|c|c|c|c|}
\hline Nematode, sample time & $\operatorname{AUROC}( \pm \mathrm{SE})^{\mathbf{a}}$ & $95 \% \mathrm{CI}^{\mathrm{b}}$ & $P^{\mathbf{c}}$ & $J^{\mathrm{d}}$ & Cut point ${ }^{\mathrm{e}}$ & Sens $^{f}$ & Spec $^{g}$ \\
\hline \multicolumn{8}{|l|}{ M. fallax } \\
\hline Planting (soil) & $0.774(0.068)$ & $0.641-0.908$ & 0.001 & 0.566 & 1.20 & 0.86 & 0.71 \\
\hline Planting (peel) & $0.532(0.092)$ & $0.352-0.712$ & 0.704 (ns) & $\ldots$ & $\ldots$ & $\ldots$ & $\ldots$ \\
\hline Harvest (peel) & $0.837(0.062)$ & $0.715-0.959$ & $<0.0001$ & 0.555 & 24.32 & 0.86 & 0.96 \\
\hline Planting (soil) + (peel) & $0.711(0.062)$ & $0.589-0.832$ & 0.012 & 0.493 & 13.87 & 0.93 & 0.56 \\
\hline Preharvest (soil) & $0.772(0.073)$ & $0.629-0.915$ & 0.001 & 0.518 & 29.33 & 0.79 & 0.73 \\
\hline \multicolumn{8}{|l|}{ M. hapla } \\
\hline Planting (soil) & $0.620(0.082)$ & $0.460-0.779$ & 0.153 (ns) & $\ldots$ & $\ldots$ & $\ldots$ & $\ldots$ \\
\hline Planting (peel) ${ }^{1}$ & $0.367(0.070)$ & $0.231-0.504$ & $0.885(\mathrm{~ns})$ & $\ldots$ & $\ldots$ & $\ldots$ & $\ldots$ \\
\hline Harvest (soil) & $0.543(0.090)$ & $0.367-0.719$ & 0.606 (ns) & $\ldots$ & $\ldots$ & $\ldots$ & $\ldots$ \\
\hline Harvest (peel) & $0.555(0.087)$ & $0.385-0.725$ & 0.512 (ns) & $\ldots$ & $\ldots$ & $\ldots$ & $\ldots$ \\
\hline \multicolumn{8}{|l|}{ M. fallax + M. hapla } \\
\hline Planting (soil) & $0.732(0.069)$ & $0.596-0.868$ & 0.006 & 0.518 & 5.21 & 0.79 & 0.73 \\
\hline
\end{tabular}

${ }^{a}$ Area under the receiver operating characteristic curve ( \pm standard error $\left.[\mathrm{SE}]\right)$

b Confidence interval (CI) for AUROC.

${ }^{c}$ Abbreviation: $\mathrm{ns}=$ not significant.

d Youden's Index.

e Cut point defined as the point on the ROC curve furthest to the diagonal line representing a noninformative predictor used to dichotomize predictions of fields

${ }^{\mathrm{f}}$ Sensitivity = percentage of fields classified correctly as being over the cut point threshold.

${ }^{\mathrm{g}}$ Specificity $=$ percentage of fields classified correctly as below the cut point threshold 
Like traditional techniques such as manual extractions, results from quantifying nematode populations in soil by DNA extraction and PCR remain limited by the practical difficulties associated with obtaining a sufficiently sized soil sample in a pattern representative of the highly heterogeneous and spatially aggregated patterns typical of plantparasitic nematodes (Rossi et al. 1992; Trangmar et al. 1986). Additional sources of error are low extraction efficiencies of nematodes for subsequent DNA extraction or of DNA directly from soil samples. Many commercial kits only extract DNA from small quantities of soil (i.e., up to $10 \mathrm{~g}$ ). In contrast, traditional nematode extraction utilizes up to $500 \mathrm{~g}$ of soil within a single sample, which is likely to provide improvements in accuracy and precision due to volume but with an inherently lower extraction efficiency. Several studies have compared the efficiencies, accuracy, and precision of commercial kits for DNA extraction from soil across common limitations encountered such as soil type and between kits and alternative manual extraction techniques (Dineen et al. 2010; Knauth et al. 2013; Mahmoudi et al. 2011; Young et al. 2014). Similarly, quantification of pathogen inoculum before planting, regardless of technique, is a simplistic indicator of risk and cannot account for factors during crop growth. These factors may also affect the relationship between initial inoculum and yield or quality loss. However, DNA techniques may provide more rapid results, improved sensitivity, the ability to identify to species for eggs and vermiform nematodes, and utility to quantify several pathogens from the same sample and extraction. Our study indicated that DNA quantification in soil at planting for root-knot nematodes was an accurate predictor of tuber damage. The accuracy of prediction was improved by using nematode DNA at planting to predict nematode DNA in tuber peel at harvest, which was associated with visual damage.

Further work to improve the accuracy of prediction of a nematode DNA test before planting could incorporate the effect of degree-day accumulation on the number of Meloidogyne spp. generations that may occur. For example, degree-day accumulation during the season was reported as more important than initial second-stage juvenile populations in the soil in determining damage caused by M. chitwoodi (Griffin 1985). Further improvement could be obtained by adjusting the time of soil sampling. Ferris et al. (1994) noted that damage to potato caused by $M$. chitwoodi was predicted with higher accuracy by manual extraction when nematode populations were estimated the previous fall in comparison with before planting in spring. Prediction accuracies may be further improved by including edaphic risk factors representative of field cropping history as developed in tomato (Stirling et al. 2004).

\section{Acknowledgments}

This project was undertaken while senior author was employed by the University of Tasmania, Australia. Funding for this project was provided by Horticulture Australia Limited through the National Vegetable and Potato Levies, with matched funding from the Australian Government (project MT09067) and the United States Department of Agriculture-National Institute for Food and Agriculture Hatch project NYG-625424, managed by The New York Agricultural Experiment Station, Cornell University, Geneva, NY. We are grateful for the technical assistance of S. Jones, C. Palmer, P. Gardam, and P. Beveridge (University of Tasmania, Australia), staff of McCains Foods [Australia] Pty. Ltd., Simplot Australia Ltd., and potato growers for access to fields. Thanks also to S. Nelson (University of Hawaii at Manoa) and C. Smart (Cornell University) for constructive comments on an earlier draft of this manuscript.

\section{Literature Cited}

Anonymous. 2007. National Standard for Certification of Seed Potatoes. Horticulture Australia Limited, Sydney, New South Wales, Australia.

Bélair, G. 1998. Seasonal and vertical distribution of Meloidogyne hapla in organic soil. Phytoprotection 79:1-8.

Bélair, G., and Boivin, G. 1988. Spatial pattern and sequential sampling plan for Meloidogyne hapla in muck-grown carrots. Phytopathology 78:604-607.

Benson, D. A., Cavanaugh, M., Clark, K., Karsch-Mizrachi, I., Lipman, D. J., Ostell, J., and Sayers, E. W. 2013. GenBank. Nucleic Acids Res. 41:D36-D42.

Berry, S. D., Fargette, M., Spaull, V. W., Morand, S., and Cadet, P. 2008. Detection and quantification of root-knot nematode (Meloidogyne javanica), lesion nematode (Pratylenchus zeae) and dagger nematode (Xiphenema elongatum) parasites of sugarcane using real-time PCR. Mol. Cell. Probes 22:168-176.

Bewick, V., Cheek, L., and Ball, J. 2004. Statistics review 13: Receiver operating characteristic curves. Crit. Care 8:508-512.
Bilodeau, G. J. 2011. Quantitative polymerase chain reaction for the detection of organisms in soil. CAB Rev. Perspect. Agric. Vet. Sci. Nutr. Nat. Resour. 6:014. DOI: 10.1079/PAVSNNR20116014

Bilodeau, G. J., Koike, S. T., Uribe, P., and Martin, F. N. 2012. Development of an assay for rapid detection and quantification of Verticillium dahliae in soil. Phytopathology 102:331-343.

Cullen, D. W., Toth, I. K., Pitkin, Y., Boonham, N., Walsh, K., Barker, I., and Lees, A. K. 2005. Use of quantitative molecular diagnostic assays to investigate Fusarium dry rot in potato stocks and soil. Phytopathology 95: $1462-1471$.

den Nijs, L. J. M. F., Brinkman, H., and van der Sommen, A. T. C. 2004. A Dutch contribution to knowledge on phytosanitary risk and host status of various crops for Meloidogyne chitwoodi Golden et al. 1980 and M. fallax Karssen 1996: An overview. Nematology 6:303-312.

Deora, A., Gossen, B., Amirsadeghi, S., and McDonald, M. R. 2015. A multiplex qPCR assay for detection and quantification of Plasmodiophora brassicae in soil. Plant Dis. 99:1002-1009.

Dineen, S. M., Aranda, R., Anders, D. L., and Robertson, J. M. 2010. An evaluation of commercial DNA extraction kits for the isolation of bacterial spore DNA from soil. J. Appl. Microbiol. 109:1886-1896.

Ferris, H., Carlson, H. L., and Westerdahl, B. B. 1994. Nematode population changes under crop rotation sequences - Consequences for potato production. Agron. J. 86:340-348.

Fischer, J. E., Bachmann, L. M., and Jaeschke, R. 2003. A readers' guide to the interpretation of diagnostic test properties: Clinical example of sepsis. Int. Care Med. 29:1043-1051.

Griffin, G. D. 1985. Host-parasite relationship of Meloidogyne chitwoodi on potato. J. Nematol. 17:395-399.

Gugino, B. K., Ludwig, J. W., and Abawi, G. S. 2008. An on-farm bioassay for assessing Meloidogyne hapla infestations as a decision management tool. Crop Prot. 27:785-791.

Haling, R. E., Simpson, R. J., McKay, A. C., Hartley, D., Lambers, H., OphelKeller, K., Wiebkin, S., Herdina, Riley, I. T., and Richardson, A. E. 2011. Direct measurement of roots in soil for single and mixed species using a quantitative DNA-based method. Plant Soil 348:123-137.

Hall, T. A. 1999. BioEdit: A user-friendly biological sequence alignment editor and analysis program for Windows 95/98/NT. Nucleic Acids Symp. Ser. 41:95.

Hanley, J. A., and McNeil, B. J. 1982. The meaning and use of the area under the receiver operating characteristic (ROC) curve. Radiology 143:29-36.

Hay, F. S., and Pethybridge, S. J. 2005. Nematodes associated with carrot production in Tasmania, Australia, and the effect of Pratylenchus crenatus on yield and quality of Kuroda-type carrot. Plant Dis. 89:1175-1180.

Insera, R. N., Griffin, G. R., and Sisson, D. V. 1982. Effect of temperature and root leachates on embryogenic development and hatching of Meloidogyne chitwoodi and M. hapla. J. Nematol. 15:123-127.

King, B. A., and Taberna, J. P., Jr. 2013. Site-specific management of Meloidogyne chitwoodi in Idaho potatoes using 1,3-dichloropropene; approach, experiences and economics. J. Nematol. 45:202-213.

Knauth, S., Schmidt, H., and Tippkötter, R. 2013. Comparison of commercial kits for the extraction of DNA from paddy soils. Lett. Appl. Microbiol. 56: 222-228.

Lloyd, C. J. 2000. Regression models for convex ROC curves. Biometrics 56 862-867.

Madani, M., Subbotin, S. A., and Moens, M. 2005. Quantitative detection of the potato cyst nematode, Globodera pallida and the beet cyst nematode, Heterodera schachtii, using real-time PCR with SYBR Green I dye. Mol. Cell. Probes 19:81-86.

Madden, L. V., Hughes, G., and van den Bosch, F. 2007. The Study of Plant Disease Epidemics. American Phytopathological Society, St. Paul, MN.

Mahmoudi, N., Slater, G. F., and Fulthrope, R. R. 2011. Comparison of commercial DNA extraction kits for isolation and purification of bacterial and eukaryotic DNA from PAH-contaminated soils. Can. J. Microbiol. 57: 623-628.

Melakeberhan, H., Mennan, S., Chen, S., Darby, B., and Dudek, T. 2007. Integrated approaches to understanding and managing Meloidogyne hapla populations' parasitic variability. Crop Prot. 26:894-902.

O'Bannon, J. H., and Santo, G. S. 1984. Effect of soil temperature on reproduction of Meloidogyne chitwoodi and M. hapla and in combination on potato and M. chitwoodi on rotation plants. J. Nematol. 16:309-312.

Ophel-Keller, K., McKay, A., Harding, R., Hall, B., Wicks, T., Wiechel, T., Crump, N., Shah, F., Marshall, J., and Falloon, R. 2009. DNA monitoring tools for soil-borne pathogens of potato. In: Australian Potato Research Program Final Report to Horticulture Australia Limited for Project PT04016, 2:1-86. I. Kirkwood, ed. Horticulture Australia Limited, Sydney, New South Wales, Australia.

Ophel-Keller, K., McKay, A., Hartley, D., Herdina, and Curran J. 2008 Development of a routine DNA-based testing service for soil-borne diseases in Australia. Australas. Plant Pathol. 37:243-253.

Pethybridge, S. J., Gent, D. H., Esker, P. D., Turechek, W. W., Hay, F. S., and Nutter, F. W., Jr. 2009. Site specific risk factors for ray blight in Tasmanian pyrethrum fields. Plant Dis. 93:229-237. 
Pinkerton, J. N., and Santo, G. S. 1986. Control of Meloidogyne chitwoodi in commercially grown Russet Burbank potatoes. Plant Dis. 70:860-863.

Rossi, R. E., Mulla, D. J., Journel, A. G., and Franz, E. H. 1992. Geostatistical tools for modeling and interpreting ecological spatial dependence. Ecol. Monogr. 62: 277-314.

Santo, G. S., and O'Bannon, J. H. 1981a. Effect of soil temperature on the pathogenicity and reproduction of Meloidogyne chitwoodi and M. hapla on Russet Burbank potato. J. Nematol. 13:483-486.

Santo, G. S., and O'Bannon, J. H. 1981b. Pathogenicity of the Columbia root-knot nematode (Meloidogyne chitwoodi) on wheat, corn, oat, and barley. J. Nematol. 13:548-550.

Shurtleff, M. C., and Averre, C. W. 2000. Diagnosing Plant Diseases Caused by Nematodes. American Phytopathological Society, St. Paul, MN.

Stevenson, W. R., Loria, R., Franc, G. D., and Weingartner, D. P. 2001. Compendium of Potato Diseases. American Phytopathological Society, St. Paul, MN.

Stirling, G. R., Griffin, D., Ophel-Keller, K., McKay, A., Hartley, D., Curran, J., Stirling, A. M., Monsour, C., Winch, J., and Hardie, B. 2004. Combining an initial risk assessment process with DNA assays to improve prediction of soilborne diseases caused by root-knot nematode (Meloidogyne spp.) and Fusarium oxysporum f. sp. lycopersici in the Queensland tomato industry. Australas. Plant Pathol. 33:285-293.

Stirling, G. R., and Wachtel, M. F. 1985. Root-knot nematode Meloidogyne hapla on potato in south-eastern South Australia. Aust. J. Exp. Agric. 25:455-457.

Taylor, A. L., and Sasser, J. N. 1978. Biology, Identification and Control of RootKnot Nematodes (Meloidogyne sp.). North Carolina State Graphics, Raleigh, NC.

Tegg, R. S., Corkrey, R., Herdina, H., McKay, A. C., Crump, N. S., de Boer, R. F., Wiechel, T. J., and Wilson, C. R. 2015. Modeling pathogen DNA content and visual disease assessment in seed tubers to inform disease in potato progeny root, stolon, and tubers. Plant Dis. 99:50-57.

Tegg, R. S., Corkrey, R., and Wilson, C. R. 2014. A comparison of potato seed-tuber sampling strategies using visual and DNA analyses to estimate incidence of major seed tuber-borne pathogens. Eur. J. Plant Pathol. 139: 359-367.
Trangmar, B. B., Yost, R. S., and Uehara, G. 1986. Applications of geostatistics to spatial studies of soil properties. Adv. Agron. 38:45-94.

Turechek, W. W., Hartung, J. S., and McCallister, J. 2008. Development and optimization of a real-time detection assay for Xanthomonas fragariae in strawberry crown tissue with receiver operating characteristic curve analysis. Phytopathology 98:359-368.

Turechek, W. W., and Wilcox, W. F. 2005. Evaluating predictors of apple scab with receiver operating characteristic curve analysis. Phytopathology 95 679-691.

van der Beek, J. G., and Karssen, G. 1997. Interspecific hybridization of meiotic parthenogenetic Meloidogyne chitwoodi and M. fallax. Phytopathology 87: 1061-1066.

Viglierchio, D. R., and Schmitt, R. V. 1983. On the methodology of nematode extraction from field samples: Comparison of methods for soil extraction. J. Nematol. 15:450-454.

Vovlas, N., Mifsud, D., Landa, B. B., and Castillo, P. 2005. Pathogenicity of the root-knot nematode Meloidogyne javanica on potato. Plant Pathol. 54:657-664.

Walker, G. E. 2000. Effects of Meloidogyne spp. and Verticillium dahliae on the growth of two Ixodia achillaeoides populations. Australas. Plant Pathol. 29: $81-85$

Whitehead, A. G., and Hemming, J. R. 1965. A comparison of some quantitative methods of extracting small vermiform nematodes from soil. Ann. Appl. Biol. 55:25-38

Yan, G. P., Smiley, R. W., and Okubara, P. A. 2012. Detection and quantification of Pratylenchus thornei in DNA extracted from soil using real-time PCR. Phytopathology 102:14-22.

Yan, G. P., Smiley, R. W., Okubara, P. A., Skantar, A. M., and Reardon, C. L. 2013. Developing a real-time PCR assay for detection and quantification of Pratylenchus neglectus in soil. Plant Dis. 97:757-764.

Youden, W. J. 1950. An index for rating diagnostic tests. Cancer 3:32-35.

Young, J. M., Rawlence, N. J., Weyrich, L. S., and Cooper, A. 2014. Limitations and recommendations for successful DNA extraction from forensic soil samples: A review. Sci. Justice 54:238-244. 